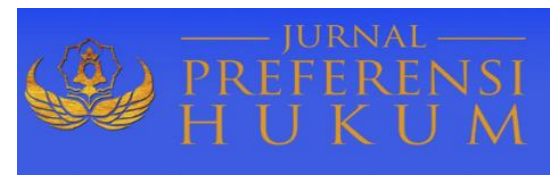

Jurnal Preferensi Hukum | ISSN: 2746-5039

Vol. 2, No. 1 - Februari 2021, Hal. 125-129| Available online at https://www.ejournal.warmadewa.ac.id/index.php/juprehum

DOI: https://doi.org/10.22225/jph.2.1.2804.125-129

\title{
KEDUDUKAN NOTARIS DALAM PEMBUATAN AKTA TERHADAP RAPAT UMUM PEMEGANG SAHAM YANG DIADAKAN MELALUI MEDIA TELEKONFERENSI
}

\author{
I Made Nova Wibawa, I Nyoman Alit Puspadma, Ida Ayu Putu Widiati \\ Fakultas Hukum Universitas Warmadewa, Denpasar-Bali, Indonesia \\ novawibawa97@gmail.com, .alitpus7@gmail.com, Widiatidayu@yahoo.com
}

\begin{abstract}
Abstrak
Undang-undang No. 40 Tahun 2007 tentang PT (Perseroan Terbatas) mengatur hal yang dapat dilakukan melalui media telekonferensidiatur pada Pasal 77 ayat (1) UUPT sehingga memungkinkan para pemegang saham melakukan RUPS tanpa harus bertemu secara langsung dan berada satu tempat melainkan dapat dilaksanakan dengan telekonferensi yang memungkinkan para pemilik saham saling melihat serta berinteraksi aktif dalam rapat. Penelitian ini bertjuan untuk menjelaskan lebih rinci bentuk-bentuk Akta Berita Acara Rapat Umum Pemegang Saham Perseroan Terbatas yang dibuat oleh Notaris dan menganalisis lebih rinci apa yang digunakan oleh notaris untuk membuat Akta Pernyataan Keputusan Rapat dalam Rapat Umum Pemegang Saham yang diselenggarakan melalui media telekonferensi. Penelitian didesain dengan menggunakan penelitian hukum normatif dengan pendekatan perundang-undangan data penelitian diperoleh melalui cara dokumentasi. Adapun sumber datanya adalah data sekunder berupa sumber hukum. Hasil penelitian menunjukkan bahwa bentuk akta otentik artinya PT dapat menentukan kesepakatan para pemilik saham apakah akan dituangkan dalam akta otentik ataupun akta dibawah tangan Risalah RUPS dengan telekonferensi yang diaplikasikan kedalam akta otentik oleh Notaris. Rapat umum yang dilaksanakan secara telekoferensi tidak sah karena melanggar ketentuan dalam Pasal 16 ayat (1) huruf m UUJN-P yang mewajibkan kehadiran secara fisik para pihak dalam proses penyusunan akta otentik sehingga kekuatan pembuktian akta di bawah tangan sebagai akibat dari adanya perbuatan yang tidak sesuai dengan Pasal 16 ayat (1) huruf $m$ tersebut.
\end{abstract}

Kata Kunci: RUPS; Media Telekonferensi; Akta Otentik

\begin{abstract}
Law No. 40 of 2007 concerning PT (Limited Liability Company) regulates what can be done through teleconference media regulated in Article 77 paragraph (1) of Company Law so that it allows shareholders to conduct a GMS without having to meet in person and be in one place but can be carried out by teleconference which allows the owners shares see each other and interact actively in meetings. This study aims to explain in more detail the forms of the Minutes of the General Meeting of Shareholders of Limited Liability Companies prepared by the second Notary to analyze in more detail what is used by the notary to make the Deed of Statement of Meeting Resolutions at the General Meeting of Shareholders held via teleconferencing media. The research was designed using normative legal research with a statutory approach. The research data were obtained through documentation. The data source is secondary data in the form of legal sources. The results showed that the form of an authentic deed means that the PT can determine the agreement of the shareholders whether it will be written in an authentic deed or a deed under the hands of the Minutes of the GMS by teleconference which is applied to the authentic deed by the Notary. The general meeting which is held by teleconference is invalid because it violates the provisions in Article 16 paragraph (1) letter $m$ UUJN-P which requires the physical presence of the parties in the process of drafting an authentic deed so that the power of proof of the deed is under hand as a result of inappropriate actions with Article 16 paragraph (1) letter $m$.
\end{abstract}

Keywords: GMS; Teleconferencing Media; Authentic deed

\section{PENDAHULUAN}

Undang-Undang No 40 Tahun 2007 tentang Perseroan Terbatas (yang selanjutnya disebut UU PT) merupakan pembaharuan dari Undang-Undang Nomor 1 Tahun 1995 yang merupakan sebuah jawaban dari berbagai persoalan dalam aktivitas dunia usaha yang dipandang belum diatur dalam Kitab Undang-Undang Hukum Dagang (KUHD) peninggalan pemerintahan kolonial Peraturan Perseroan Terbatas dirasakan sangat sumir karena hanya terdiri dari 21 (dua puluh satu) pasal saja sementara disisi lain berbagai perkembangan dalam kegiatan usaha maupun bisnis mengalami perkembangan 
yang sangat cepat sehingga tidak dapat lagi dijangkau oleh KUHD oleh karena itu salah satu jalan untuk memberi jawaban terhadap perubahan tersebut adalah menyesuaikan ketentuan- ketentuan yang terdapat dalam KUHD dengan segala perubahan yang terjadi sehingga dibuat Undang-Undang Nomor 1 Tahun 1995 sebagai pengganti dari KUHD.

Teknologi dapat meningkatkan kualitas dan jangkauan apabila digunakan secara bijak untuk pendidikan dan latihan, dan mempunyai arti yang sangat penting bagi kesejahteraann (Budiman, 2017). Seiring perkembangan zaman yang berimplikasi dengan berkembangnya teknologi dalam kehidupan bermasyarakat yang sangat berpengaruh dalam kegiatan usaha maka dalam UUPT tersebut telah menyesuaikannya dimana diatur dalam peraturan tentang penyelenggaraan RUPS melalui media telekonferensi sesuai Pasal 77 ayat 1 UUPT menyatakan bahwa RUPS dapat dilaksanakan dengan media telekonferensi video konferensi atau media elektronik lainnya yang dapat memfasilitasi anggota partisipasi RUPS untuk dapat saling mendengar melihat juga berpartisipasi langsung dalam rapat (Nadapdap, 2012).

Apabila dicermati bahwa ketentuan dalam Pasal tersebut diatas yang memungkinkan melakukan RUPS dengan media telekonferensi tersebut bertentangan dengan peraturan yang terdapat dalam Undang-Undang Nomor 30 tahun 2004 Jo Undang-Undang Nomor 2 Tahun 2014 tentang perubahan atas Undang-Undang Nomor 30 tahun 2004 tentang Jabatan Notaris (selanjutnya disebut UUJN-P).

Pertentangan/konflik norma akan terjadi apabila risalah RUPS melalui media telekonferensi tersebut akan dituangkan ke dalam sebuah akta otentik Konflik norma akan terjadi antara Pasal 77 ayat (1) UUPT tersebut dengan Pasal 16 ayat (1) huruf M UUJN-P inti dari pasal ini menyatakan bahwa Notaris memiliki kewajiban antara lain membacakan akta di depan pengahdap dihadiri paling sedikit 2 (dua) orang saksi ataupun 4 (empat) orang saksi terutama untuk pembuatan akta wasiat dibawah tangan dan pada saat itu juga ditanda tangani oleh Notaris saksi dan penghadap.

Ada beberapa penelitian terdahulu terkait penelitian ini yaitu Budiman, (2017) mengungkapkan bahwa Pelaksanaan rapat secara telekonferensi tidak dapat dibuat berita acaranya mengingat ketentuan pasal 16 ayat (1) huruf $m$ UUJN-P notaris harus hadir secara fisik dan menandatangani akta dihadapan penghadap dan saksi, penelitian lain mengungkapkan bahwa Mekanisme pembuatan Akta Berita Acara RUPS melalui telekonferensi oleh Notaris dilakukan dengan keikutsertaan Notaris melalui media telekonferensi sejak awal hingga berakhirnya RUPS yang didasarkan pada undangan dari direksi dan wilayah Jabatan Notaris (Hasbullah, 2016). Dengan perkembangan teknologi diharapkan akan terciptanya aturan hukum secara khusus tentang Cyber Notary, yang memanfaatkan perkembangan teknologi informasi dalam pelaksanaan tugas Notaris sehingga teknologi yang semakin canggih bisa membantu untuk memepermudah berkembangnya hukum di Indonesia (Widyaswari, 2019). Penelitian ini bertujuan untuk menjelaskan lebih rinci bentuk-bentuk akta berita acara rapat umum pemegang saham perseroan terbatas yang dibuat oleh Notaris yang kedua menganalisis lebih rinci apa yang digunakan oleh notaris untuk membuat Akta Pernyataan Keputusan Rapat dalam Rapat Umum Pemegang Saham yang diselenggarakan melalui media telekonferensi.

\section{METODE PENELITIAN}

Penelitian ini menggunakan penelitian hukum normatif. Penelitian hukum normatif merupakan tahapan yang digunakan untuk memperoleh data untuk selanjutnya dapat digunakan untuk tujuan tertentu (Sugiyono, 2013). Pendekatan yang digunakan adalah pendekatan perundang-undangan yang menggunakan legislasi dan regulasi. Pendekatan perundang-undangan dilakukan dengan menelaah semua undang-undang dan regulasi yang berkaitan dengan isu hukum yang sedang dihadapi, yakni perihal ketentuan pelaksanaan hukum akta RUPS yang dilaksanakan melalui media elektronik atau telekoferensi. Data penelitian diperoleh melalui cara dokumentasi. Adapun sumber datanya adalah data sekunder berupa sumber hukum dan dianalisis dengan logikan deduktif.

\section{HASIL DAN PEMBAHASA}

\section{Bentuk-Bentuk Akta Berita Acara Rapat Umum Pemegang Saham Perseroan Terbatas yang dibuat oleh Notaris}

Notaris risalah RUPA pada suatu Perseroan dapat dituangkan dalam akta partij atau akta pihak maupun kedalam akta relaas terdapat 2 (dua) jenis akta otentik yaitu akta yang dibuat dihadapan Notaris yang disebut akta partij atau akta pihak dan akta yang dibuat oleh Notaris yang disebut akta relaas (Hably \& Djajaputra, 2019). Menurut Pramono, (2015) Akta partij memiliki unsur sebagai berikut: 
a. Berisikan keterangan dari pihak-pihak yang tercantum dalam akta

b. Agar akta tersebut memperoleh otentitas sebagai akta otentik harus terdapat syarat utama yaitu tanda tangan.

c. Isi akta tersebut dapat digugat kebenarannya tanpa dibatasi hanya dengan menggunakan alasan bahwa akta tersebut palsu

Akta relaas merupakan akta yang dibuat oleh Notaris yang menerangkan secara otentik suatu perbuatan yang diperbuat atau suatu keadaan yang disaksikan oleh Notaris dalam menjalankan jabatannya yang memiliki unsur yaitu penejelasan Notaris sebagai pejabat umum tentang kesaksian atas semua yang dilihat disaksikan dan dialaminya dalam suatu tindakan dari pihak- pihak dalam akta berkaitan dengan tugas seorang Notaris, apabila para pihak tidak menandtangani akta yang dibuat hal ini tidak menjadikan akta tersebut tidak otentik, selanjutnya akta tersebut hanya dapat digugat dengan alasan akta tersebut palsu alasan diluar itu tidak diterima (Sajadi, 2015).

Akta relaas disusun oleh Notaris berlandaskan pada keterangan para pihak selanjutnya Notaris menuliskan atau mencatat seluruh penjelasan yang diterangkan oleh berhubungan dengan perbuatan hukum atau perbuatan lainnya yang dilaksanakan para pihak agar perbuatan tersebut dibuat atau dicantumkan dalam suatu akta Notaris (Adjie, 2008).

Mengenai bentuk akta yang akan dibuat oleh Notaris terhadap Risalah RUPS suatum Perseroan dapat mengacu pada Pasal 90 ayat (1) dan (2) serta Pasal 91 UUPT Pada Pasal 90 menyebutkan bahwa pada pelaksanaan RUPS Risalah RUPS harus disusun dan ditandatangani oleh pimpinan rapat dan minimal 1 orang pemilik saham yang dipilih oleh peserta rapat dan apabila risalah RUPS dibuat secara otentik maka tanda tangan tersebut tidaklah menjadi syarat serta pada pasal 91 diterangkan bahwa Keputusan mengikat selain dalam RUPS dapat diambil oleh pemegang saham apabila pemegang saham menyetujui dan menandatangani usul yang bersangkutan.

Terkait dengan Pasal 90 ayat (2) UUPT tersebut maka bentuk akta otentik yang dibuat oleh Notaris adalah akta relaas atau akta pejabat (ambtelijke acta) Risalah RUPS yang dibuat oleh Notaris berdasarkan bentuk akta ini adalah notaris sebagai pejabat umum diminta untuk dapat menghadiri RUPS yang akan diselenggarakan oleh suatu Perseroan Terbatas dengan terlebih dahulu mendapatkan undangan dari Perseroan Terbatas yang bersangkutan di dalam undangan tersebut tertera tentang waktu dan tempat serta agenda RUPS dengan hadirnya Notaris pada pelaksanaan RUPS Perseroan tersebut maka seorang Notaris menyaksikan apa yang disaksikan serta dialaminya saat berlangsungnya RUPS dari apa yang telah disaksikan pada RUPS tersebut Notaris menuangkannya ke dalam sebuah akta otentik dimana dalam akta tersebut Notaris memberikan keterangan tentang apa yang dilihat didengar dan keputusan yang dihasilkan dalam RUPS Perseroan tersebut kemudian ditandatangani oleh para pemegang saham saksi-saksi dan Notaris. Bentuk akta pejabat ini disebut dengan akta berita acara rapat umum pemegang saham atau akta partij.

\section{Akta Pernyataan Keputusan Rapat dalam Rapat Umum Pemegang Saham Melalui Media Telekonferensi}

Cirri-ciri akta otentik sebagai berikut:

a. Akta Otentik

Akta otentik adalah alat bukti mutlak yang tercantum dalam pasal 1870 Kitab Undang- undang Hukum Perdata memberikan diantara para pihak termasuk para ahli warisnya atau orang yang mendapat hak dari para pihak itu suatu bukti yang mutlak mengenai apa yang diperbuat dalam akta ini yang artinya memiliki kekuatan bukti sempurna karena dianggap melekatnya pada akta itu sendiri sehingga tidak perlu dibuktikan lagi dan untuk hakim sebagai bukti wajib/keharusan. Berdasarkan hal itu maka barang siapa yang menggugat denan alasan akta otentik itu palsu maka yang bersangkutan wajib untuk membuktikan mengenai ketidak aslian akta itu dengan hal ini maka akta otentik mempunyai kekuatan pembuktian baik lahiriah formil maupun materiil.

b. Akta dibawah tangan

Akta dibahawah tangan adalah bukti bebas disebabkan akta dibawah tangan baru akan memiliki kekuatan bukti materiil setelah dibuktikan kekuatan formilnya akan tetapi kekuatan pembuktian formilnya baru terjadi bila pihak-pihak terkait mengetahui mengenai kebenaran muatan dan cara pembuatan akta itu. Apa bila akta dibawah tangan dinyatakan palsu maka yang menggunakan akta dibawah tangan itu sebagai bukti wajib membuktikan bahwa akta itu tidak palsu (NG Yudara 2006) Untuk dapat menyatakan suatu akta otentik telah memenuhi syarat 
formal Terdapat 3 unsur utama yaitu memiliki bentuk berdasarkan ketentuan undang-undang, Pembuatannya dihadapan pejabat umum, selanjutnya akta yang dibuat harus didepan dan dihadapan pejabat umum yang memiliki wewenang dalam hal itu serta ditempat sesuai akta itu dibuat (Soerodjo, 2003). Dalam setiap kepentingan bisnis aktivitas dibidang perbankan pertanahan kegiatan sosial dan lain sebagainyakebutuhan mengenai pembuktian tertulis dalam bentuk akta otentik akan semakin diperlukan seiring dengan bervariasinya kepentingan dan kepastian hukum dalam setiap hubungan ekonomi dan sosial baiktingkat nasional regional maupun global. Jadi mengenai RUPS dengan media telekonferensi yang diatur pada Pasal 77 ayat (1) UUPT tersebut tidak dapat diaplikasikan menjadi sebuah akta relaas/akta pejabat oleh Notaris karena ketidak hadiran secara fisik namun Risalah RUPS tersebut dapat dituangkan dalam sebuah akta partij/akta yang disusun didepan Notaris dimana sebuah Perseroan Terbatas telah terlebih dahulu mengadakan RUPS melalui media telekonferensi ditempat kedudukan mana Perseroan Terbatas tersebut dan hasil dari RUPS tersebut telah dibuatkan suatu berita acara ditandatangani oleh seluruh peserta rapat secara elektronik. Berdasrka ayat (4) Pasal 77 UUPT dapat dilihat bahwa pada pelaksanaan RUPS secara telekonferensi harus disusun risalah rapat dan harus disepakati dan ditandatangani oleh seluruh anggota partisipasi RUPS berdasar ketentuan itu ada diketahu bahwa perbedaan penyusunan dan penandatanganan risalah RUPS secara telekonferensi dengan RUPS konvensional serta dalam penjelasan dari Pasal 77 ayat (4) UUPT tersebut dijelaskan bahwa maksud dari disetujui dan ditandatangani adalah disetujui dan ditandatangani secara fisik atau secara elektronik. Mengacu pada pasal itu maka RUPS secara telekonferensi dapat ditandatangani dengan cara:

a. Ditandatangani secara fisik bagi seluruh partisipasi RUPS

b. Ditandatangani secara elektronik bagi seluruh partisipasi RUPS

c. Ditandatangani masing-masing sebagian oleh partisipasi RUPS secara fisik serta secara elektronik.

Setelah dilaksanakannya RUPS melalui media telekonferensi tersebut maka dibuatlah berita acara RUPS dibawah tangan dimana dalam berita acara rapat tersebut memberikan kuasa kepada direktur untuk menghadap kepada seorang Notaris agar berita acara RUPS dibawah tangan tersebut dapat dibuatkan suatu akta otentik, dengan menghadapnya seorang direktur mewakili perseroan berdasarkan kuasa dari Perseroan Terbatas tersebut maka akta yang disusun Notaris merupakan sebuah akta partij bentuk akta partij ini disebut dengan akta pernyataan keputusan rapat umum para pemegang saham

\section{SIMPULAN DAN SARAN}

\section{Simpulan}

Berdasarkan hasil analisis data dapat disimpulkan bahwa Akta yang dibuat oleh (door) notaris atau akta relaas atau akta pejabat Risalah RUPS yang dibuat oleh Notaris dan pejabat yang berwenang disebut bentuk akta berita acara rapat umum pemegang saham. Akta yang dibuat dihadapan (ten overstaan) notaris atau akta partij (partij akten) Risalah RUPS yang disusun dihadapan Notaris dan merupakan sebuah akta partij ketika sebuah Perseroan Terbatas telah terlebih dahulu melaksanakan RUPS ditempat kedudukan Perseroan Terbatas tersebut dimana hasil dari RUPS tersebut telah dibuatkan suatu berita acara dan ditanda tangani oleh para pemegang saham komisaris dan direktur serta dalam berita acara RUPS yang dibuat dibawah tangan tersebut memberikan kuasa kepada direktur untuk menghadap kepada seorang Notaris agar berita acara RUPS dibawah tangan tersebut dapat dibuatkan suatu akta otentik. Dengan menghadapnya seorang direktur mewakili perseroan berdasarkan kuasa dari Perseroan Terbatas tersebut maka akta yang dibuat oleh Notaris merupakan sebuah akta partij disebut dengan Akta Pernyataan Keputusan Rapat Umum Para Pemegang Saham, yang kedua RUPS secara telekonferensi hanya dapat diaplikasikan dalam bentuk akta partij oleh Notaris karena bertentangan dengan ketentuan pasal 16 ayat (1) huruf m UUJN-P yang mengharuskan kehadiran secara fisik dan menandatangani akta dihadapan penghadap dan saksi.

\section{Saran}

Berdasarkan temuan dalam penelitian ini, peneliti memberikan saran yaitu Untuk dapat mendirikan suatu Perseroan Terbatas harus dengan akta otentik yang dibuat oleh Notaris sehingga memperoleh pengesahan dari Kementerian Hukum dan Hak Asasi Manusia begitu pula hendaknya jika sebuah 
Perseroan Terbatas menyelenggarakan RUPS agar menuangkan hasil dari keputusan atau risalah RUPS tersebut ke dalam sebuah akta otentik guna memiliki kekuatan pembuktian yang sempurna, yang kedua Perlu diadakan revisi terhadap (UUJN-P) khususnya ketentuan yang tertuang dalam Pasal 16 ayat (1) huruf $m$ agar sesuai dengan kemajuan teknologi yang semakin pesat dimana kecanggihan teknologi dewasa ini memungkinkan para pihak untuk bertransaksi tanpa harus bertemu secara fisik

\section{DAFTAR PUSTAKA}

Adjie, H. (2008). Hukum Notaris Indonesia Tafsir Tematik terhadap UU No 30 Tahun 2004 tentang Jabatan Notaris. Refika Aditama.

Budiman, H. (2017). Peran Teknologi Informasi dan Komunikasi dalam Pendidikan. Jurnal Pendidikan Islam, $8(1), 75-83$.

Hably, R. U., \& Djajaputra, G. (2019). Kewenangan Notaris dalam Hal Membuat Akta Partij. Jurnal Hukum Adigama, 2(2), 482.

Hasbullah. (2016). Legalitas (Keabsahan) Akta Notaris terhadap Rapat Umum Pemegang Saham Melalui Media Telekonferensi. Jurnal Lamlaj, 1(1), 90-98.

Nadapdap, A. B. (2012). Hukum Perseroan Terbatas. Permata Aksara.

Pramono, D. (2015). Kekuatan Pembuktian Akta yang Dibuat oleh Notaris. Lex Jurnalica, 12(3), 248-258.

Sajadi, I. (2015). Tanggung Jawab Notaris Terhadap Keabsahan Akta Notaris yang Dibuatnya atas Penghadap yang Tidak Dapat Membaca dan Menulis. Jurnal Repertorium, 2(2).

Soerodjo, I. (2003). Kepastian Hukum Hak Atas Tanah di Indonesia. Arkola.

Sugiyono. (2013). Metode Penelitian Pendidikan Pendekatan Kuantitatif dan Kualitatif. Alfabeta.

Widyaswari, N. M. D. N. (2019). Perlindungan Hukum bagi Para Pihak dalam Pembuatan Akta RUPS yang Dilaksanakan Melalui Media Telekonferensie. Jurnal Vyavahara Duta, 15(1), 62-71. 